\title{
ASSESSMENT OF ORGANIC CARBON IN WETLANDS AND RIPARIAN ZONE. CASE STUDY: COMMON FLOODPLAIN OF JIJIA-PRUT RIVERS, ROMANIA
}

DOI: http://dx.doi.org/10.18509/GBP.2018.05

UDC: 556.512(498)

\author{
Mădălina Pascal', \\ Elena Diana Bobric ${ }^{1,2}$, \\ ${ }^{1}$ Alexandru Ioan Cuza University of Iasi, Faculty of Geography and Geology, Department of \\ Geography, Carol I 20A, 700505, Iasi, Romania \\ ${ }^{2}$ Alexandru Ioan Cuza University of Iasi, CERNESIM, 11 Carol I Bld., 700506 Iasi, Romania
}

\begin{abstract}
The evaluation of organic carbon contributes to the delimitation of wetlands in the context of the degradation of the edaphic shell in the temperate zone. The quantification of the total carbon (TC) and the total organic carbon (TOC) from the soil is a key analysis in regards to the management of soil quality. In the common floodplain of Jijia-Prut rivers, the hydrotechnical and agricultural facilities deeply changed the aquatic scenery, lowering the organic carbon quantity, and deeply impacting the biodiversity of the relict wetlands. Currently, the hydromorphic soils are affected both by natural factors (climate change, the changing of the soil's texture, the diminution of the areas covered by natural vegetation, and in situ biodegradation) as well as anthropogenic factors (irrational land usage). This study targets the evaluation of TC and TOC quantities from the transition perimeters of the wetlands corresponding to common floodplain of Jijia-Prut rivers. The analysis was realized on 55 ground samples collected from 5 reference points. The samples were collected using a pedological corer from the summer of 2016. In order to determine the organic carbon, we used a TOC analyzer equipped with a solid sample module, operated at $1,000^{\circ} \mathrm{C}$ (Analytik Jena multi N/C with HT 1300). The values were situated between $6.61 \mathrm{~g} / \mathrm{kg}$ and $45.02 \mathrm{~g} / \mathrm{kg}$, with an average of $19.98 \mathrm{~g} / \mathrm{kg}$. The highest values were registered in the wetlands that were the least anthropogenically affected. The lowest values correspond to the areas from outside the aquatic perimeter. The drop in TOC is directly proportional to the diminution of wetlands and riparian zone.
\end{abstract}

Keywords: biodiversity, riparian zone, soil, wetlands, TOC

\section{INTRODUCTION}

In recent decades, wetlands and riparian areas have undergone a severe global degradation process [1-3]. Reducing areas with excess humidity has a negative impact on biodiversity conservation as well as on local communities that are economically and socially dependent on natural resources [4]. The assessment of total carbon (TC) and total organic carbon (TOC) in hydromorphic soils has contributed over time to the delimitation of wetlands and riparian areas in the temperate zone [1].

Variation in organic carbon may indicate changes in soil due to land use, climate change, or hydro- and agro-technical work that has reduced organic carbon storage capacity in the soil [4]. In practice, three methods for estimating organic carbon are used: wet dichromate oxidation (WO), dry combustion (DC) and loss of ignition (LOI) [5-12]. In this study we 
determined the total carbon and total organic carbon in 5 transition perimeters of the wetlands and riparian zone corresponding to common floodplain of Jijia-Prut rivers using the method DC [13-15]. The results contribute to a more precise delimitation of the humidity areas in NE from Romania.

\section{CASE STUDY: COMMON FLOODPLAIN OF JIJIA-PRUT RIVERS}

The common floodplain of Jijia Prut Rivers is located in the northeastern part of Romania (the central-southern area of the Moldavian Plain). The western limit (the Prut River) is the natural border between Romania and the Republic of Moldova (Figure 1a). From the administrative point of view, the study area is located in the county of Iasi (20 communes). The morphometric parameters are: the surface $-515.34 \mathrm{~km}^{2}$, the length $89.45 \mathrm{~km}$, the max. - $19.41 \mathrm{~km}$ (north of the area), min. - $3.26 \mathrm{~km}$ (south of the area) (Figure 1b) [1, 16-20].

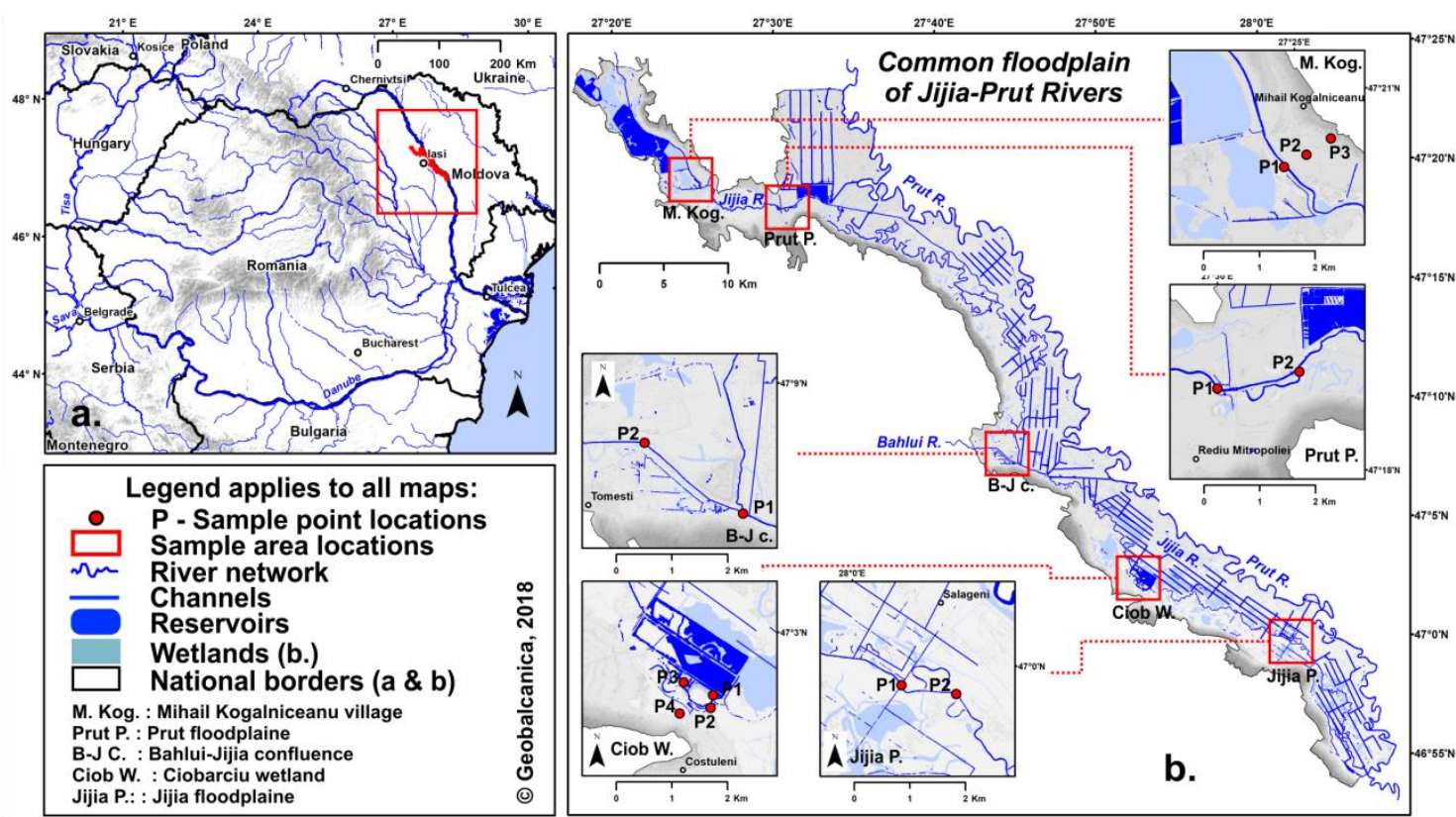

Figure 1. a. Geographic location of the common floodplain of Jijia-Prut Rivers on the Eastern border of Romanian; b. Soil sample sites within study area: M. Kog. (P1-3) - Mihail Kogalniceanu village; Prut P. (P1-2) - Prut floodplain; B-J c. (P1-2) - Bahlui-Jijia confluence; Ciob W. (P1-4) - Ciobarciu wetland; Jijia P. (P1-2) - Jijia floodplain

From a hydro-geomorphological and biogeographical point of view, the area is a representative unit for the Moldavian Plain. The lower part of the Jijia floodplain is carved in clay and sandy clay which causes a high natural turbidity of water [16-18]. In altitude, the meadow is dominated by the interfluvial peaks that make up the right bank of the Prut $(<280 \mathrm{~m})$. The minimum altitudes $(>20 \mathrm{~m})$ correspond to the confluence of Jijia-Prut (Gura Bohotin). Between the two water courses, a $5 \mathrm{~m}$ long longitudinal grind was developed higher than the drainage level, which led to the formation of a common work over a distance of approx. 50-60 km [1].

The wetlands in the study area are a consequence of the hydro-technical arrangement of the middle and lower course of Jijia and the middle course of the Prut. Prior to the Communist era, a large natural area with excess humidity was formed between the two hydrographic arteries [16]. At present, most water bodies have been turned into farmyard 
farms, farmland, drinking water supply basins, or floods to mitigate floods. The total aquatic area represents $5.01 \%$ of the total area under consideration $\left(25.85 \mathrm{~km}^{2}\right)$ and is a consequence of water resource management for fisheries and agro-zootechnical purposes. Aquatic habitats in the Jijia-Prut meadow have a particular ecological potential to support biodiversity [1, 17-20].

\section{METHODS AND TECHNIQUES}

The assessment of TC and TOC content has been achieved whitin the transition perimeters of the wetlands corresponding to common floodplain of Jijia-Prut rivers. The analysis was realized on 55 ground samples collected from 5 reference points: Mihail Kogalniceanu village (M. Kog.) (Table 1), Prut floodplain (Prut P.) (Table 2), BahluiJijia confluence (B-J c.) (Table 3), Ciobarciu wetland (Ciob W.) (Table 4), and Jijia floodplain (Jijia P.) (Table 5). The samples were collected using a pedological corer from the summer of 2016. TOC content was determined by the difference between TC and total inorganic carbon (TIC), measured directly with the Analytik Jena Multi N/C 2100 analyser equipped with a module for solid samples: HT 1300 - High-temperature combustion technology [13-15]. Solid samples were treated by increasing temperature up to $1000^{\circ} \mathrm{C}$ for $\mathrm{TC}$ as well as after manually acidified with $\mathrm{HCl} 2 \mathrm{M}$ to $\mathrm{pH} 2$ and dried in an oven for TIC [13, 14, 21-29].

\section{RESULTS AND DISCUSSION}

Site 1. Mihail Kogalniceanu village (M. Kog.). The site is located on the regular course of Jijia, downstream of PISCICOLA Iasi $\left(47^{\circ} 21^{\prime} 22.23^{\prime \prime N}, 2^{\circ} 23^{\prime} 57.37^{\prime \prime E}\right)$. The water course was dammed for flooding: river system, subsystem - perennial inferior course, substrate - small river and fine alluvium, hydrological regime - permanent flooding [1]. The major meadow was heavily modified anthropically, currently being affected by intensive grazing and agricultural practice $[17,18]$.

Three samples were collected to determine TOC: P1 - the alluvial water substrate (TOC range between $6.61-11.05 \mathrm{~g} / \mathrm{Kg}$ ); $\mathrm{P} 2$ - the left bank of the minor bed with TOC between $13.6245 .02 \mathrm{~g} / \mathrm{Kg}$ ); P3 - on the first alluvial terrace with TOC varies from 25.54 to 37.9 $\mathrm{g} / \mathrm{Kg}$ ). In this context, the organic carbon content is under the influence on water erosion and transport (P1), flood frequency and aquatic vegetation degradation (P2), and soilspecific pedogenetic processes (P3). The wetland boundary occurs between $\mathrm{P} 2$ and $\mathrm{P} 3$ at the contact between the minor bed and the first terrace (Table 1).

Table 1. Depth variation of TC and TOC content within the site M. Kog.

\begin{tabular}{|c|c|c|c|c|c|c|}
\hline \multirow{2}{*}{$\begin{array}{c}\text { Depth } \\
(\mathrm{cm})\end{array}$} & \multicolumn{5}{|c|}{ Site name / Code : Mihail Kogalniceanu village - M. Kog. } \\
\cline { 2 - 7 } & \multicolumn{2}{|c|}{ P1 } & \multicolumn{2}{c|}{ P2 } & \multicolumn{2}{c|}{ P3 } \\
\cline { 2 - 7 } & $\mathrm{TC}(\mathrm{g} / \mathrm{Kg})$ & $\mathrm{TOC}(\mathrm{g} / \mathrm{Kg})$ & $\mathrm{TC}(\mathrm{g} / \mathrm{Kg})$ & $\mathrm{TOC}(\mathrm{g} / \mathrm{Kg})$ & $\mathrm{TC}(\mathrm{g} / \mathrm{Kg})$ & $\mathrm{TOC}(\mathrm{g} / \mathrm{Kg})$ \\
\hline $0-10$ & 25.81 & 11.05 & 56.51 & 45.02 & 38.26 & 25.54 \\
\hline $10-20$ & 23.31 & 9.98 & 34.98 & 24.27 & 48.26 & 35.88 \\
\hline $20-30$ & 17.93 & 8.49 & 20.9 & 16.13 & 47.77 & 37.9 \\
\hline $30-40$ & 27.37 & 8.06 & 26.17 & 13.62 & - & - \\
\hline $40-50$ & 25.58 & 6.61 & - & - & - & - \\
\hline
\end{tabular}

Site 2. Prut floodplain (Prut P.). The site is located in the floodplain between the regular course of Jijia and the natural course of the Prut $\left(47^{\circ} 19^{\prime} 31.56^{\prime \prime} \mathrm{N}, 27^{\circ} 28^{\prime} 40.77^{\prime \prime} \mathrm{E}\right)$. The 
wetland has the following characteristics: lake system, limestone subsystem, non consolidated substrate (shore, alluvium), hydrological regime - permanent / seasonal flooding [1]. The meadow has been anthropically modified to reduced floods, with intensive grazing and / or for raising domestic birds in the vegetation season [17]. The groundwater level is near the topographic surface [18].

Two samples were collected to determine TOC: P1 - the minor bed of regularized Jijia with TOC in he range $19.4-30.14 \mathrm{~g} / \mathrm{Kg}$ ); $\mathrm{P} 2$ - the minor bed of the old natural course of Jijia (TOC varies between $23.18-36.95 \mathrm{~g} / \mathrm{Kg}$ ). In this context, the organic carbon content depends on solid transport (P1) or stagnation and degradation of aquatic vegetation in situ (P2). There are no significant differences between the two samples because water erosion is not significant. An important role in flood mitigation is played by complex hydrotechnical works in this meadow sector (Table 2).

Table 2. Depth variation of TC and TOC content within the site Prut P.

\begin{tabular}{|c|c|c|c|c|}
\hline \multirow{3}{*}{$\begin{array}{c}\text { Depth } \\
(\mathrm{cm})\end{array}$} & \multicolumn{4}{|c|}{ Site name / Code : Prut floodplain - Prut P. } \\
\hline & \multicolumn{2}{|c|}{$\mathrm{P} 1$} & \multicolumn{2}{|c|}{$\mathrm{P} 2$} \\
\hline & $\mathrm{TC}(\mathrm{g} / \mathrm{Kg})$ & TOC $(\mathrm{g} / \mathrm{Kg})$ & $\mathrm{TC}(\mathrm{g} / \mathrm{Kg})$ & TOC $(\mathrm{g} / \mathrm{Kg})$ \\
\hline $0-10$ & 32.64 & 25.31 & 38.1 & 36.95 \\
\hline $10-20$ & 37.99 & 30.14 & 38.26 & 36.04 \\
\hline $20-30$ & 31.3 & 25.24 & 41.43 & 31.5 \\
\hline $30-40$ & 30.5 & 19.4 & 32.31 & 23.18 \\
\hline
\end{tabular}

Site 3. Bahlui-Jijia confluence (B-J c.). The site is located at the confluence of the Jijia River with the industrial floodplain of the Bahlui River $\left(47^{\circ} 07^{\prime} 44.80^{\prime \prime} \mathrm{N}, 27^{\circ} 44^{\prime} 12.75^{\prime \prime} \mathrm{E}\right)$. The water course has been modified due to the industrial activities in the area: river system, subsystem - perennial inferior course, substratum - shore and fine alluvius, hydrological regime - permanent flooding [1]. The confluence area retains some natural features but the hydrological regime and water quality have been strongly modified [1719] (Table 3).

Table 3. Depth variation of TC and TOC content within the site B-J c.

\begin{tabular}{|c|c|c|c|c|}
\hline \multirow{2}{*}{$\begin{array}{c}\text { Depth } \\
(\mathrm{cm})\end{array}$} & \multicolumn{3}{|c|}{ Site name / Code: Bahlui-Jijia confluence - B-J c. } \\
\cline { 2 - 5 } & \multicolumn{3}{|c|}{$\mathrm{P} 1$} & $\mathrm{~T}$ \\
\hline & $\mathrm{TC}(\mathrm{g} / \mathrm{Kg})$ & $\mathrm{TOC}(\mathrm{g} / \mathrm{Kg})$ & $\mathrm{TC}(\mathrm{g} / \mathrm{Kg})$ & $\mathrm{TOC}(\mathrm{g} / \mathrm{Kg})$ \\
\hline $0-10$ & 31.14 & 14.43 & 33 & 17.12 \\
\hline $10-20$ & 30.46 & 14.95 & 34.55 & 17.37 \\
\hline $20-30$ & 32.77 & 16.03 & 34.34 & 17.36 \\
\hline $30-40$ & 27.55 & 13.25 & 28.67 & 17.12 \\
\hline $40-50$ & 27.31 & 13.18 & 35.11 & 24.5 \\
\hline
\end{tabular}

Two samples were collected to determine TOC: P1- minor meadow downstream Jijia (TOC $\min 13.18 \mathrm{~g} / \mathrm{Kg}$, TOC $\max , 16.03 \mathrm{~g} / \mathrm{Kg}$ ); P2 - the minor meadow of upstream Bahlui (TOC varies from $17.2 \mathrm{~g} / \mathrm{Kg}$ to $24.5 \mathrm{~g} / \mathrm{Kg}$ ). In this context, the organic carbon depends for both samples on water dynamics. In case of sample P1, water velocity and vegetation-free riparian area cause a decrease of TOC, while in the perimeter of $\mathrm{P} 2$, downstream of the confluence of the two water courses, the increase of TOC content is determined by the reduced water speed and the development of aquatic vegetation associations. For P1 the wetland is limited at the boundary of the aquatic surface, and for P2 this gradually developed from downstream to the upstream boundary (Table 3 ). 
Site 4. Ciobarciu wetland (Ciob W.). The site is located on the old course of Jijia, where several fishing grounds $\left(47^{\circ} 02^{\prime} 30.65^{\prime \prime} \mathrm{N}, 27^{\circ} 52^{\prime} 00.02^{\prime \prime} \mathrm{E}\right)$ were arranged. Currently, the area has re-entered into the natural vegetation circuit as a consequence of Jijia's hydrotechnical development upstream of this sector. The area has a natural reservation status and includes two partially drained fish enclosures and their drainage system, all of which are located in the Costuleni area. The interior of the reservation is occupied by large areas with reeds: palustral system, class - wet temporary emerged area, hydrological regime temporary flooding [1].

4 samples were collected to determine TOC: P1 - the alluvial substrate of the fishery area (with TOC range between $14.92-28.17 \mathrm{~g} / \mathrm{Kg}$ ); P2 - the alluvial substrate of the drainage channel (TOC varies between $11.84-44.92 \mathrm{~g} / \mathrm{Kg}$ ); P3 - the area with hygrophilous vegetation between the fishery area and the drainage channel (TOC vary from 12.93 $26.29 \mathrm{~g} / \mathrm{Kg}$ ); P4 - the limitrophe area of the reservation, at the boundary between the protected wetland and Jijia alluvial meadow (TOC values ranges from 12.35 to 27.07 $\mathrm{g} / \mathrm{Kg}$ ). The TOC depends on the biodegradation environment of the vegetation, with significant values in the case of P2 due to water stagnation. For samples P1, P3 and P4 there are no significant differences. This phenomenon can be explained by the normalization of the natural conditions of organic matter accumulation. The limit of the wetland includes both the fishing area and their surroundings [1, 17-19] (Table 4).

Table 4. Depth variation of TC and TOC content within the site Ciob W.

\begin{tabular}{|c|c|c|c|c|c|c|c|c|}
\hline \multirow{3}{*}{$\begin{array}{l}\text { Depth } \\
(\mathrm{cm})\end{array}$} & \multicolumn{8}{|c|}{ Site name / Code : Ciobarciu wetland - Ciob W. } \\
\hline & \multicolumn{2}{|c|}{ P1 } & \multicolumn{2}{|c|}{$\mathrm{P} 2$} & \multicolumn{2}{|c|}{ P3 } & \multicolumn{2}{|c|}{ P4 } \\
\hline & $\begin{array}{c}\mathrm{TC} \\
(\mathrm{g} / \mathrm{Kg})\end{array}$ & $\begin{array}{c}\text { TOC } \\
(\mathrm{g} / \mathrm{Kg})\end{array}$ & $\begin{array}{c}\mathrm{TC} \\
(\mathrm{g} / \mathrm{Kg})\end{array}$ & $\begin{array}{c}\text { TOC } \\
(\mathrm{g} / \mathrm{Kg})\end{array}$ & $\begin{array}{c}\mathrm{TC} \\
(\mathrm{g} / \mathrm{Kg})\end{array}$ & $\begin{array}{c}\text { TOC } \\
(\mathrm{g} / \mathrm{Kg})\end{array}$ & $\begin{array}{c}\mathrm{TC} \\
(\mathrm{g} / \mathrm{Kg})\end{array}$ & $\begin{array}{c}\text { TOC } \\
(\mathrm{g} / \mathrm{Kg})\end{array}$ \\
\hline $0-10$ & 31.57 & 28.17 & 49.54 & 44.94 & 25.95 & 12.93 & 43.39 & 27.07 \\
\hline $10-20$ & 15.45 & 15.87 & 24.89 & 12.62 & 37.27 & 26.29 & 39.3 & 25.48 \\
\hline $20-30$ & 13.29 & 14.92 & 23.74 & 11.84 & 27.96 & 16.28 & 27.27 & 12.35 \\
\hline $30-40$ & 19.76 & 19.17 & 20.85 & 20.49 & 25.31 & 17.71 & - & - \\
\hline $40-50$ & 15.46 & 21.02 & 15.39 & 15.6 & 25.98 & 14.45 & - & - \\
\hline
\end{tabular}

Site 5. Jijia floodplain (Jijia P.). The site is located in the lower part of Jijia's natural course $\left(46^{\circ} 58^{\prime} 56.73^{\prime \prime} \mathrm{N}, 28^{\circ} 01^{\prime} 59.66^{\prime \prime} \mathrm{E}\right)$. The wetland has the following characteristics: river system, subsystem - perennial inferior course, unconsolidated shore, hydrological regime - permanent flooding [1]. The hydrological regime was heavily modified due to the upstream of Jijia intakes. The meadow is well individualized, in this sector being used for agrozootechnical purposes (arable land, pastures) [17]. To determine the TOC, two samples were collected: P1 - the alluvial substrate of the natural water course (with TOCmin $12.94 \mathrm{~g} / \mathrm{Kg}$ and TOCmax, $16.31 \mathrm{~g} / \mathrm{Kg}$ ); P2 - the left shore of the natural water course (TOCmin $13.26 \mathrm{~g} / \mathrm{Kg}$, TOCmax $27.13 \mathrm{~g} / \mathrm{Kg}$ ). In this context, the organic carbon content depends on in situ biodegradation (P1) or anthropic (P2) changes (Table 5).

At the level of the entire study area, TC content were situated between $13.29 \mathrm{~g} / \mathrm{kg}$ and $56.21 \mathrm{~g} / \mathrm{kg}$, with an average of $30.39 \mathrm{~g} / \mathrm{kg}$, and TOC content were situated between 6.61 $\mathrm{g} / \mathrm{kg}$ and $45.02 \mathrm{~g} / \mathrm{kg}$, with an average of $19.98 \mathrm{~g} / \mathrm{kg}$. Significant differences between TC and TOC have been identified in the case of samples collected from water bodies: P1 Mihail Kogalniceanu village sector (M. Kog.); P1 and P2 - Bahlui-Jijia confluence (B-J c.); P1 - Jijia floodplain (Jijia P.). The highest values of TOC were registered in the wetlands that were the least anthropogenically affected: Jijia River in the Mihail Kogalniceanu village sector (M. Kog.) and Ciobarciu Wetland (Ciob W.). The lowest values of TOC correspond to the areas from outside the aquatic perimeter. The drop in 
TOC values is directly proportional to the diminution of wetlands and riparian zone and with increased of water erosion (Fig. 2).

Table 5. Depth variation of TC and TOC content within the site Jijia P.

\begin{tabular}{|c|c|c|c|c|}
\hline \multirow{2}{*}{$\begin{array}{c}\text { Depth } \\
(\mathrm{cm})\end{array}$} & \multicolumn{4}{|c|}{ Site name / Code : Jijia floodplain - Jijia P. } \\
\cline { 2 - 5 } & \multicolumn{3}{|c|}{$\mathrm{P} 1$} & \multicolumn{2}{c|}{$\mathrm{P} 2$} \\
\cline { 2 - 5 } & $\mathrm{TC}(\mathrm{g} / \mathrm{Kg})$ & $\mathrm{TOC}(\mathrm{g} / \mathrm{Kg})$ & $\mathrm{TC}(\mathrm{g} / \mathrm{Kg})$ & $\mathrm{TOC}(\mathrm{g} / \mathrm{Kg})$ \\
\hline $0-10$ & 32.08 & 16.31 & 35 & 27.13 \\
\hline $10-20$ & 25.77 & 13.25 & 26.23 & 15.17 \\
\hline $20-30$ & 24.39 & 14.68 & 26.38 & - \\
\hline $30-40$ & 34.88 & 13.76 & - & - \\
\hline $40-50$ & 24.64 & 12.94 & - & - \\
\hline
\end{tabular}
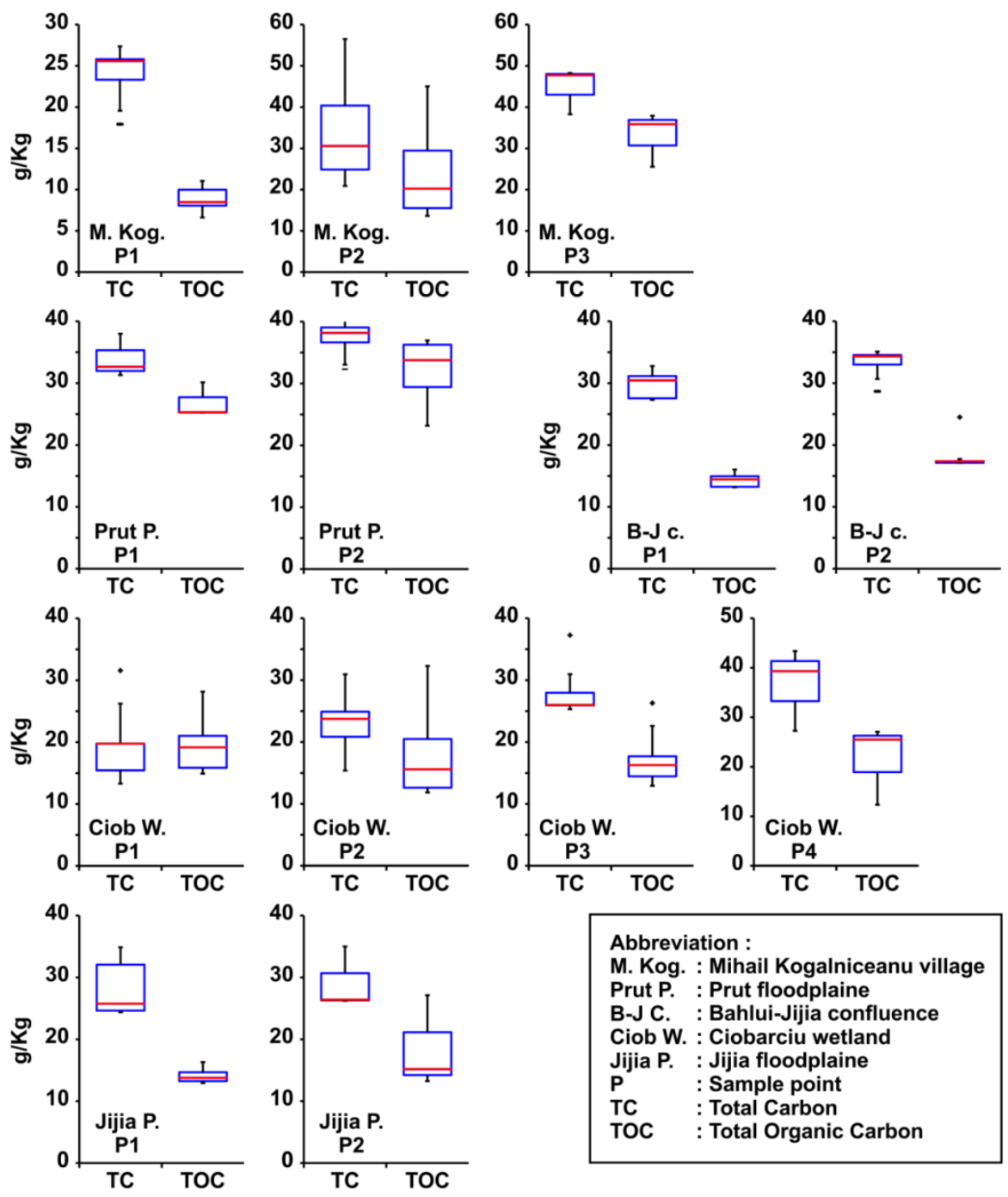

Abbreviation :
M. Kog. : Mihail Kogalniceanu village
Prut P. : Prut floodplaine
B-J C. : Bahlui-Jijia confluence
Ciob W. : Ciobarciu wetland
Jijia P. : Jijia floodplaine
P : Sample point
TC : Total Carbon
TOC : Total Organic Carbon

Figure 2. Box plot showing the median, $25^{\text {th }}$ and $75^{\text {th }}$ percentiles, and outliers values of TC and TOC content in the first $40 \mathrm{~cm}$ for each soil sample.

\section{CONCLUSIONS}

The TC and TOC sequestered in the soil layers of the wetlands and riparian zone is strongly related to climatic changes, vegetation, soil texture and water management. In the common floodplain of Jijia-Prut rivers (NE Romania), the hydrotechnical and 
agricultural facilities deeply changed the aquatic scenery, lowering the organic carbon quantity, and deeply impacting the biodiversity of the relict wetlands. The analysis realized on 55 ground samples collected from five reference points indicates an TOC content situated between $6.61 \mathrm{~g} / \mathrm{kg}$ and $45.02 \mathrm{~g} / \mathrm{kg}$, with an average of $19.98 \mathrm{~g} / \mathrm{kg}$. The highest values of TOC were registered in the wetlands and riparian zone. The lowest values of TOC correspond to the areas from outside the aquatic perimeter. The results contribute to a more precise delimitation of the wetlands in NE Romania.

\section{ACKNOWLEDGMENTS}

This work was financial supported by the Department of Geography from the "Alexandru Ioan Cuza" University of Iasi, Romania, and the infrastructure was provided through the POSCCE-O 2.2.1, SMIS-CSNR 13984-901, No. 257/28.09.2010 Project, CERNESIM (L4) and Geoarchaeology Laboratory.

\section{REFERENCES}

[1] Romanescu G., Pascal M., Mihu-Pintilie A., Stoleriu C.C., Sandu I. \& Moisii, M. Water Quality Analysis in Wetlands Freshwater: Common Floodplain of Jijia-Prut Rivers, Revista de chimie, Romania, vol. 68(3), pp. 553-561, 2017.

[2] Adopo K.L., Romanescu G., N'Guessan A.I. \& Stoleriu C. Relations between man and nature and environmental dynamics at the mouth of the Komoé river, Grand-Bassam (Ivory Coast), Carpathian Journal of Earth and Environmental Sciences, vol. 9, no. 4, pp. 137-148, 2014.

[3] Adopo K.L., N'Guessan M.Y., Sandu A.V., Romanescu G. \& Sandu I.G. The spatial distribution and characterization of sediments and the bottom morphology of the hydroelectric lake in Ayamé 2 (Ivory Coast), International Journal of Conservation Science, vol. 7, no. 2, pp. 567-578, 2016.

[4] Romanescu G., Sandu I., Stoleriu C. \& Sandu I.G. Water Resources in Romania and Their Quality in the Main Lacustrine Basins, Revista de Chimie (Bucharest), Romania, vol. 65, no. 3, pp. 344-349, 2014.

[5] Bisutti I., Hilke I. \& Raessler M. Determination of total organic carbon - an overview of current methods, TrAC - Trends in Analytical Chemistry, vol. 23, no. 10-11, pp. 716-726, 2004.

[6] Chatterjee A., Lal R., Wielopolski L., Martin M.Z. \& Ebinger M.H. Evaluation of different soil carbon determination methods, Critical Reviews in Plant Science, vol. 28, no. 3, pp. 164-178, 2009.

[7] Sleutel S., De Neve S., Singier B. \& Hofman G. Quantification of organic carbon in soils: A comparison of methodologies and assessment of the carbon content of organic matter, Communications in Soil Science and Plant Analysis, vol. 38, pp. 2647-2657, 2007.

[8] Wang Q.R., Li Y.C. \& Wang Y. Optimizing the weight loss-on-ignition methodology to quantify organic and carbonate carbon of sediments from diverse sources, Environmental Monitoring and Assessment, vol 174, pp. 241-257, 2011.

[9] Rabenhorst M.C. Determination of organic and carbonate carbon in calcareous soils using dry combustion, Soil Science Society of America Journal, vol. 52, pp. 965-969, 1988.

[10] Salehi M.H., Beni O.H., Harchegani H.B., Borujeni I.E. \& Motaghianh R. Refining Soil Organic Matter Determination by Loss-on-Ignition, Pedosphere, vol. 21, no. 4, pp. 473-482.

[11] Jankauskas B., Slepetiene A., Jankauskiene G., Fullen M.A. \& Booth C.A. A comparative study of analytical methodologies to determine the soil organic matter content of Lithuanian Eutric Albeluvisols, Geoderma, vol. 136, pp. 763-773, 2006. 
[12] Edu E.M., Mihalache M. \& Ionescu M. Determination of organic carbon in forest soils by comparative analysis of methods: Walkley Black method with the Gogoasa modification versus dry combustion Dumars method, Research Journal of Agricultural Science, Romania, vol. 45, no. 1, pp. 13-20, 2013.

[13] Bobric E.D., Rusu E., Melniciuc-Puica N. \& Breaban I.G. Investigation of carbon content from Neamtu catchment soils using FTIR spectroscopy, Journal of Environmental Protection and Ecology, Greece, vol. 19, no. 1, pp. 507-514, 2018.

[14] Breaban I.G., Bobric E.D., Rusu E. \& Secu C.V. Soil organic matter assessment from Neamtu catchment soils through various organic carbon methods, SGEM2017 Conference Proceedings, Geoconference on Soil, Bulgaria, vol. 17, no. 32, pp. 507-514, 2017. Doi:10.5593/sgem2017/32/S13.066

[15] Mihu-Pintilie A., Asandulesei A., Nicu I.C., Stoleriu C.C. \& Romanescu G. Using GPR for assessing the volume of sediments from the largest natural dam lake of the Eastern Carpathians: Cuejdel Lake, Romania, Environmental Earth Sciences, vol. 75, no. 710, 2016. Doi: 10.1007/s12665-016-5537-1

[16] Breaban I.G., Paiu M., Mihu-Pintilie A. \& Cretescu I. Using multivariate statistical methods to assess drinking water quality from urban water supply in Iasi city, Romania, SGEM2014 Conference Proceedings, Geoconference on Water Resources, Forest, Marine and Ocean Ecosystems, Bulgaria, vol. 1, pp. 815-822, 2014. Doi: 10.5593/SGEM2014/B31/S12.104

[17] Romanescu G. \& Stoleriu C. Exceptional floods in the Prut basin, Romania, in the context of heavy rains in the summer of 2010, Natural Hazards and Earth System Sciences, vol. 17, pp. 381-396, 2017.

[18] Romanescu G., Cimpianu C.I., Mihu-Pintilie A. \& Stoleriu C.C. Historic flood events in NE Romania (post-1990), Journal of Maps, vol. 13, no. 2, pp. 787-798, 2017.

[19] Romanescu G., Mihu-Pintilie A., Stoleriu C.C., Carboni D., Paveluc L.E. \& Cimpianu C.I. A Comparative Analysis of Exceptional Flood Events in the Context of Heavy Rains in the Summer of 2010: Siret Basin (NE Romania) Case Study, Water, vol. 10, no. 2, 216, pp. 1-17, 2018. Doi: $10.3390 /$ w 10020216

[20] Mihu-Pintilie A., Paiu M., Breaban I.G. \& Romanescu G. Status of water quality in Cuejdi hydrographic basin from Eastern Carpathian, Romania, SGEM2014 Conference Proceedings, Geoconference on Water Resources, Forest, Marine and Ocean Ecosystems, Bulgaria, vol. 1, pp. 639-646, 2014. Doi:10.5593/SGEM2014/B31/S12.083

[21] Romanescu G., Dinu C., Radu A. \& Torok L. Ecologic characterization of the fluviatile limans in the south-west Dobrudja and their economic implications (Romania), Carpathian Journal of Earth and Environmental Sciences, vol. 5, no. 2, pp. 25-38, 2010.

[22] Romanescu G., Jora I. \& Stoleriu C. The most important high floods in Vaslui river basin causes and consequences, Carpathian Journal of Earth and Environmental Sciences, vol. 6, no. 1, pp. 119-132, 2011.

[23] Romanescu G., Zaharia C. \& Stoleriu C. Long-term changes in average annual liquid flow river Miletin (Moldavian Plain), Carpathian Journal of Earth and Environmental Sciences, vol. 7, no. 1, pp. 161-170, 2012.

[24] Romanescu G., Stoleriu C. \& Lupascu A. Biochemistry of wetlands in barrage Lacul Rosu catchment (Haghimas - Eastern Carpathian), Environmental Engineering and Management Journal, vol. 11, no. 9, pp. 1627-1637, 2012.

[25] Romanescu G. Alluvial Transport Processes and the Impact of Anthropogenic Intervention on the Romanian Littoral of the Danube delta, Ocean \& Coastal Management, vol. 73, pp. 31-43, 2013. 
[26] Romanescu G., Cretu M.A., Sandu I.G., Paun E. \& Sandu I. Chemism of Streams Within the Siret and Prut Drainage Basins: Water Resources and Management, Rev. Chim. (Bucharest), vol. 64, no. 12, pp. 1416-1421, 2013.

[27] Romanescu G., Zaharia C., Paun E., Machidon O. \& Paraschiv V. Depletion of watercourses in north-eastern Romania. Case study: the Miletin river, Carpathian Journal of Earth and Environmental Sciences, vol. 9, no. 1, pp. 209-220, 2014.

[28] Romanescu G. \& Stoleriu C. Anthropogenic interventions and hydrological-risk phenomena in the fluvial-maritime delta of the Danube (Romania), Ocean \& Coastal Management, vol. 102, pp. 123-130, 2014.

[29] Romanescu G., Chalov S., Stoleriu C.C., Mihu-Pintilie A., Angileri S.E., Kuznetsova Y., Cama M. \& Maerker M. Geomorphologic map of the 1st Mutnaya River, Southeastern Kamchatka, Russia, Journal of Mountain Science, vol. 14, no. 2, pp. 2373-2390, 2017. 